\title{
Reviewing the effect of student mentoring on the academic performance of undergraduate students identified as 'at risk'
}

\section{Chris S. Maharaj}

University of the West Indies, St. Augustine, Trinidad and Tobago

\section{Erik Blair}

University of West London

\section{Margo Burns}

University of the West Indies, St. Augustine, Trinidad and Tobago

\section{Abstract}

This paper outlines an early intervention programme based upon the belief that being proactive rather than reactive increases a student's academic and social success. Twentyone students from a cohort of 40 who were identified as being 'at risk' participated in a threesession mentoring programme. Grade-point averages (GPAs) were recorded pre- and postintervention, for both the intervention group and those who did not participate in the programme. Results are interpreted through the lens of Attribution Theory - in which outcomes are related to how perceived challenges are addressed. The results show that, on average, the GPAs for those who received mentoring improved by $35 \%$ between semester 1 and semester 2, whereas the non-intervention group only increased their GPAs by an average of $15 \%$.

Keywords: mentoring; grade-point average; attainment; Attribution Theory.

\section{Introduction}

Admission to undergraduate programmes primarily revolves around an academic evaluation of potential students based upon standardised national tests. This reliance on standardised 
measures means that interviews, designed to identify the challenges a student may face, are rarely used as part of the admission process (Lowe and Johnston, 2008). New students face many challenges (Jemal, 2012), and intervention programmes can improve students' academic success (Morisano et al., 2010); therefore, it is important to examine the means of support for students identified as being 'at risk' so as to evaluate whether they can help increase student engagement and attainment (Cedefop, 2020).

Early intervention programmes are based upon the belief that being proactive rather than reactive increases a student's academic and social success. Research supports this premise (Foss et al.; 2014, Zhang et al., 2014; Harmening and Jacob, 2015), particularly when proactive or early-intervention programmes address common challenges such as time management, study habits, skill development in self-regulation, and critical thinking (Kausar, 2010; Gentry, 2012; 2014). For students to successfully navigate programme-related challenges, both academic advising (promoting retention) and mentoring (promoting selfefficacy) are needed (Johnson, 2007; Crocker et al., 2014). Loddick and Coulson (2020) found that the impact of learning development tutorials on students was 'not just student attainment, but also how it improves their confidence and engagement in their studies' (p.21). Further, early intervention programmes that provide opportunities for discussions about concerns beyond academic issues create stronger faculty-student relationship bonds and have a positive impact on student well-being, academic success and retention rates (Armstrong, 1996; Johnson, 2007; Gentry, 2012; Foss et al., 2014; Harmening and Jacob, 2015). This paper relates the experiences of implementing an early-intervention mentoring programme for undergraduate Mechanical Engineering students at a Caribbean university. Undergraduate engineering students often struggle with balancing academic and psychosocial needs (AWE, 2005; Gentry, 2012; 2014) and may benefit from early intervention mentoring that encompasses both advising and mentoring; therefore, this cohort is an ideal sample for understanding the possible impact of mentoring.

Within the fields of science, technology, engineering and mathematics (STEM), the literature tends to focus on the key overarching debates: the underrepresentation of women (Fox, 2001; England and Li, 2006; Sax, 2008) and the underrepresentation of people of colour 
(Linley and George-Jackson, 2013; Fouad and Santana, 2017). In addressing these important issues, mentoring has focused on approaches that address stereotypes, low aspirations, structural racism, and structural bias. For example, Chesler and Chesler (2002) looked at peer, multiple and collective mentoring of female engineering students, and McCoy et al., (2015) unpicked the various biases of attempting 'colorblind mentorship'. However, this particular intervention was not intended to address some of these overarching concerns, but to examine a more local issue - students with low grades. It was for this reason that a broad learning development approach was applied and that is why a broad theoretical approach (Attribution Theory) was used in this study.

\section{Mentoring}

The capacity to address challenges associated with student well-being (social, emotional, physical and spiritual), and an ability to manage a variety of commitments, are linked to students' academic success and identity development (Armstrong, 1996; Kausar, 2010; Harmening and Jacob, 2015), as well as their capacity to purposefully engage with academic faculty (Gentry, 2012; Crocker et al., 2014). The traits associated with subjective well-being include emotional stability, desire for control, and private collective self-esteem (DeNeve and Cooper, 1998). Self-esteem is facilitated when there are opportunities to build self-confidence via effort, persistence and skills accrual (Katz, 1993). Increased self-confidence may, in turn, lead to a willingness to engage in more social activities, which can then lead to the development of a stronger support system.

There are two broad approaches used in higher education to enhance student well-being: academic advising and mentoring. Both of these interventions are recognised methods for increasing faculty-student interaction (Komarraju et al., 2010) and are designed to create opportunities for discussing challenges associated with adjusting to university life and wellbeing (AWE, 2005; Johnson, 2007). While many different definitions of academic advising and mentorship can be found in the literature, the general consensus is that the role of the advisor is to guide the student through an institution's academic requirements, whereas a 
mentor acts as a developer of skills, encouraging students to reach their full potential (Eby et al., 2007; Eby et al., 2008; Decker et al., 2014). Whilst academic advising is associated with facilitating academic success (Young-Jones et al., 2013), mentoring programmes have greater success in creating ongoing positive faculty-student relationships - especially when these are built upon addressing predetermined challenges and motivation identified through admission surveys or observations of programme-based student cohorts (Lipton et al., 2003; Gentry, 2012; Harmening and Jacob, 2015).

Mentoring, when used as an intervention method, has been shown to benefit students (Shelton, 2003). In addition to academic achievement, mentoring has a positive influence on behaviour, attitude, health, interpersonal relationships, motivation and career progression (Eby et al., 2008). Campbell and Campbell (2007) suggests a positive correlation between time spent on mentoring and the potential benefits of mentoring. Shelton (2003) found that students who persisted in a nursing programme perceived significantly greater psychological and functional faculty support than students who withdrew, and similar results regarding retention were found in a study on retaining female engineering students which found that mentoring in the first two years of a programme increased student retention rates (AWE, 2005).

Mentors act as guides, teachers, counsellors and skill developers (Eby et al., 2007) and use the process to build trust with the student. Zachary (2000) describes mentoring as 'a process of engagement' with a focus on 'the learner, the learning process, and learning' (p. xviii). Acting as a guide requires an open-minded, open-ended, questioning process aimed at identifying and addressing specific challenges. Mentoring, as an early intervention method, consists of both a functional role, with faculty assisting students to develop their professional skills (Mullen, 2007), and a psychosocial, or emotional, function concentrating on rolemodelling which promotes self-worth and competence. In her study on student-faculty interaction, Shelton (2003, p.339) found that students who perceived faculty as 'approachable, respectful and available for frequent interaction outside the classroom' reported greater academic self-confidence. Results from a study conducted by Zhang et al. 
(2014) on the impact of an early intervention programme, also support a proactive and person-centred approach using developmental advising (mentoring) techniques.

Research on mentoring suggests that informal mentoring which is not managed, structured or officially recognised and often not sanctioned by the institution is more effective than formal assigned mentoring (Crocker et al., 2014). Mullen (2007) found informal mentoring of graduate students produced stronger and more purposeful relationships than those produced through formal mentoring. However, in institutionally structured systems, such ad hoc approaches can be difficult to quantify and working below the radar of institutional frameworks also means that there is little wider support (Mclntosh and Bardon, 2019). Therefore, mentoring has the potential to impact student outcomes, but other, wider, factors also determine the success of the mentoring programme itself. Other significant challenges to mentoring include ensuring that mentors, in their interactions with mentees, facilitate the exchange of knowledge/experiences, provide an atmosphere for creative dialogue (Arsenijević et al., 2020) and do not try to simply impose their will.

\section{The research context}

The purpose of this paper is to review the impact of a quasi-informal early intervention mentoring programme on the grade-point average (GPA) and course failure rates of 21 undergraduate Mechanical Engineering students at a Caribbean university who were defined as academically 'at risk'. The goal of the intervention was to improve student grades. The underlying assumption was that an improved student GPA could redound in improved future success (academic and overall well-being) for the student during and after university. At the university under study, students enrolled in any undergraduate or graduate programme are required to attend an academic advising session prior to registering for courses. Advising is different for each programme, and the advisor may be an administrative assistant or a faculty member. Students in the Mechanical and Manufacturing Engineering Department are assigned a specific advisor according to their level $(1,2$ or 3$)$ in the programme. Academic advising sessions initiated at the start of each academic year are designed to guide students 
through course selection and registration. Occasionally students may have failed a prerequisite course necessitating realignment of the student's progress through a programme. Once the educational aspects of the advising process are completed, the contact between the advisor and the student typically ends. When students perceive that further help is needed to realign coursework or to navigate the administration system, they may again seek guidance from the advisor.

It is, of course, tricky to determine the number of students who need help in relation to those who come forward seeking help. Many students may not actually come forward, and research in the field of student mental wellness suggests that those students with the greatest need are less likely to come forward (Wilson and Deane, 2010; Gould et al., 2004). However, the academic advising sessions are presented as student-friendly and student-focused so as to offer the greatest chance of engagement. The advisor guides the student through the institution's educational processes, but the programme is not designed to address challenges associated with academic success, well-being or in creating strong faculty-student relationships. Such concerns are broadly deemed to be the remit of student services, where there is support for academic writing skills, and services associated with addressing financial, medical and psychosocial needs are offered.

In addition to the academic advising session, the university organises a year-long set of activities for all new undergraduate and graduate students. Activities include orientation events, a university administration orientation, a forum for parents/guardians, workshops on developing practical study habits, workshops on health and well-being, and an orientation for commuting students. While students are encouraged to attend and participate in the scheduled events, these are not mandatory, and there is no formal mentoring process introduced as part of the university's sanctioned first-year activities (mentoring in this context is defined as a faculty-student relationship created through assignment of the student to a specific faculty member who academically advises and provides psychosocial support). Undergraduate and graduate Engineering programmes at the university, including those in Mechanical and Manufacturing Engineering, are clustered under the Faculty of Engineering. The undergraduate engineering programmes are three years in length, and most students 
enter directly from secondary school. Most first-year engineering students are under the age of 19 and may be living away from home for the first time. Student residences are available providing a support system - however, students are not required to live on campus.

Admission to the Faculty of Engineering is based solely upon academic standing. There is no interview step included in the admission process, limiting institutional knowledge of the potential challenges students may face. Once admitted, students find that programmes within the Faculty use a combination of coursework and final examinations as assessment methods. Completion of a capstone or final project is required during the last year of study, which allows the student to demonstrate acquisition of the knowledge, skills and attitudes expected of a graduating engineering student. Students receive a grade for each course which converts into a GPA scheme ranging from 0 (lowest) to 4.3 (highest).

At the end of the first semester of the academic year 2014-2015, a higher than expected failure rate was reported in the Mechanical Engineering programme. Other than academic advising, which addressed course selection, no pre-existing intervention method was used to support engineering students at academic risk. The failure rates suggested that the academic advising process was not broad enough to address many challenges associated with academic failure - where failure has been found to have both dispositional factors, such as an individual student's characteristics (confidence, attitude, beliefs etc.), and situational factors regarding their wider environment (health, family, accommodation etc.) (Ajjawi et al., 2019). An alternative early intervention method to address academic challenges, student retention and overall student well-being was needed.

The Mechanical Engineering faculty met to discuss their observations of challenges faced by students. A list of nine challenges emerged. A review of the literature on challenges faced by engineering students provided overall themes in which to cluster the items. These challenges were then juxtaposed with five themes drawn from the work of Armstrong (1996), Harmening and Jacob (2015), and Kausar (2010). These themes are relationships, time management, psychosocial well-being, learning environment, and intrinsic motivation. Based upon the initial list of challenges and themes, a series of questions was developed (see Table 1). 
Table 1. Challenges, themes and questions.

\begin{tabular}{|c|c|c|}
\hline Challenge List & Theme & Questions asked \\
\hline $\begin{array}{l}\text { 1. Concentration in } \\
\text { class }\end{array}$ & Relationships & $\begin{array}{l}\text { - How would you describe your relationship } \\
\text { with family and friends? }\end{array}$ \\
\hline \multirow{4}{*}{$\begin{array}{l}\text { 2. Class attendance } \\
\text { 3. Exercise and } \\
\text { regularity } \\
\text { 4. Motivation to learn } \\
\text { 5. Relationship issues } \\
\text { 6. Study outside class } \\
\text { 7. Health concerns } \\
\text { 8. Sleep time } \\
\text { 9. Commute time }\end{array}$} & $\begin{array}{l}\text { Time } \\
\text { management }\end{array}$ & $\begin{array}{l}\text { - Do you live on campus or commute? } \\
\text { - How far do you have to commute? } \\
\text { - What methods or technologies do you use to } \\
\text { manage your time? }\end{array}$ \\
\hline & $\begin{array}{l}\text { Psychosocial } \\
\text { well-being }\end{array}$ & $\begin{array}{l}\text { - What sports, co-curricular or student guild } \\
\text { activities are you engaged in? } \\
\text { - Do you have any health issues that might } \\
\text { hinder your academic progress? } \\
\text { - Do you have any financial issues? } \\
\text { - } \text { Are you working either on or off campus? } \\
\text { - Tell me about your eating habits. }\end{array}$ \\
\hline & $\begin{array}{l}\text { Learning } \\
\text { environment }\end{array}$ & $\begin{array}{l}\text { - How many hours are you studying outside } \\
\text { the classroom? } \\
\text { - Are you attending every class? } \\
\text { - What distractions are you noticing when in } \\
\text { class? } \\
\text { - What assessments are you struggling with? }\end{array}$ \\
\hline & $\begin{array}{l}\text { Intrinsic } \\
\text { motivation }\end{array}$ & $\begin{array}{l}\text { - Do you feel ready to learn the course } \\
\text { content? } \\
\text { - What motivates you to study? } \\
\text { - What learning activities motivate you? }\end{array}$ \\
\hline
\end{tabular}

\section{Methodology}

A quasi-informal early-intervention mentoring programme was implemented during the second semester of the academic year 2014-2015. The mentoring process focused on students who had been identified as academically 'at risk' at the end of the first semester. 
This particular academic year was used for this study, as it included a higher than average failure rate, and the term 'at risk' describes students who are considered, through faculty review, to have a higher probability of failing academically. Specifically, for this study, an 'at risk' student would have failed at least one course in the previous semester (before the mentoring intervention). The intervention drew on research associated with mentoring and with Attribution Theory (Martinko, 2018), which is 'centered upon the belief that retrospective causal attributions have bearing on present and future motivation and achievement' (AWE, 2005, p.2). Attribution Theory explains the difference in motivation between high and low achievers and particularly emphasises that failure is not a result of bad luck or poor exam design, but instead is related to how perceived challenges are addressed. Attribution Theory can be used as the foundation for building an early intervention based upon examining students' self-perceptions about their abilities and efforts as they navigate their course of studies.

Forty students from a mixed student cohort comprising Level 1 and Level 2 were identified as 'at risk' at the end of their first semester. Students were invited to undertake a mentoring programme. It should be noted that this was the last cohort to receive one-to-one mentoring. Subsequent cohorts were supported through group mentoring. Further analysis of whether one-to-one or group mentoring are more suitable interventional tools is not yet complete; therefore, this paper only reports on the one-to-one intervention. Twenty-two students volunteered to participate in the intervention, but one student dropped out, leaving a final group of 21 students in the mentoring intervention. As this was a self-selecting intervention, the non-volunteering students were not pursued to engage with the mentoring programme, but a watchful eye was maintained on their overall progress, and permission was obtained to use their data as part of the control group.

Degree awards at the university range from a First-Class Honours (highest) to a Pass degree (lowest). The identified students represented a range of grade-point averages from 0.14 to 2.93, suggesting that 10 might attain a Lower Second-Class Honours degree (GPA 2.002.99), that 14 were on track for a Third-Class Honours degree (GPA 1.50-1.99), seven were likely to be awarded a Pass degree (GPA 1.00-1.49), and that the remaining eight might fail 
altogether $($ GPA $<1.00)$. Table 2 provides an overview of the GPAs of the mentored and nonmentored cohorts, and their mean GPAs of 1.78 and 1.71, respectively, show that the two cohorts were similar (with no significant difference in their initial mean scores).

Table 2. GPA of students identified as 'at risk'.

\begin{tabular}{|c|c|}
\hline Mentored cohort & Non-mentored cohort \\
\hline 0.14 & 0.55 \\
\hline 0.25 & 0.78 \\
\hline 0.51 Student dropped out & 1.03 \\
\hline 0.58 & 1.06 \\
\hline 0.72 & 1.14 \\
\hline 0.86 & 1.42 \\
\hline 0.99 & 1.53 \\
\hline 1.14 & 1.58 \\
\hline 1.14 & 1.62 \\
\hline 1.40 & 1.74 \\
\hline 1.55 & 1.76 \\
\hline 1.58 & 1.81 \\
\hline 1.63 & 1.91 \\
\hline 1.66 & 2.07 \\
\hline 1.74 & 2.49 \\
\hline 1.80 & 2.67 \\
\hline 1.93 & 2.74 \\
\hline 2.07 & 2.83 \\
\hline \multicolumn{2}{|l|}{2.49} \\
\hline \multicolumn{2}{|l|}{2.74} \\
\hline \multicolumn{2}{|l|}{2.82} \\
\hline \multicolumn{2}{|l|}{2.93} \\
\hline Mean mentored group GPA & 1.78 \\
\hline Mean non-mentored group GPA & 1.71 \\
\hline Mean GPA of all students 'at risk' & 1.74 \\
\hline
\end{tabular}

\section{Early intervention mentoring programme}

A three-session early intervention programme was implemented for the participating students. During the first session the mentor met with each student for 30 to 60 minutes. Drawing on Attribution Theory, the guiding questions (see Table 1) were used to help students identify the causal attributions of their current status. From this review, specific challenges were identified, and solutions recommended. Some students were referred to medical or 
counselling services depending upon need and based upon the university's referral process. Student responses, solutions and referrals were recorded. Based upon responses and required referrals, an action plan with solutions was developed for each student, without a formal contract (as the mentoring process was designed to build trust between the faculty member and student rather than create an institutionally-oriented procedure). An example of solutions in an action plan for one particular student (designated ' $S$ ' in the study) included reducing the occurrence of sleeping during class time by ensuring adequate night-time sleep was obtained; sitting in the class in a position where distractions due to chatter from friends and others was minimised; engaging in some form of exercise (weight lifting was chosen) every two days, and spending approximately 2 hours per day in study time with a study group. Students were advised to schedule a second appointment if they required additional support prior to the 'check-in' session.

The second mentoring session was a mid-semester 'check-in' designed to keep students on track and follow up on the recommended solutions. The session was also designed to continue building a strong faculty-student relationship. Additional recommendations and referrals were made if required. A maximum of 60 minutes was allocated per session. Student responses, solutions and referrals were recorded.

The third and final session was an end-of-semester mentoring session centred on the student's progress, including the utilisation of recommended solutions. This session, which occurred prior to the exam period, allowed for the reinforcement of study and time management techniques discussed in previous sessions. As needed, additional referrals were initiated using the university's referral process. A maximum of 60 minutes was allocated per session. Student responses, solutions and referrals were recorded.

\section{Measuring success}

For the purpose of this study, two broad measures of success were adopted: (1) A positive change in GPA, and (2) a reduction in course failure. In further examining these measures, improvements in the results of students $(n=21)$ who had undertaken the intervention were 
examined in relation to the overall outcomes of all students identified as 'at risk' $(n=39)$.

Student strategies for success were also examined. Armstrong (1996, p.2) asks an important question in her work on engineering student course load: 'Is the only measure of success an ability to pass engineering exams?'. Whilst this intervention was primarily outcome focused, using GPA as a key measure, GPA was always seen as a proxy for wider success (which is harder to quantify) where it has been found that academic achievement is positively related to emotional and psychological wellbeing (Gräbel, 2017).

\section{Findings}

Participating students completed the three intervention mentoring sessions. In relation to the measures of success, there was clear evidence of an overall positive change in GPA and a reduction in course failure. The participants had previously failed at least one course; however, this failure rate was significantly reduced following the intervention (see Table 3). The overall pre-intervention GPA average for the 21 intervention students was 1.78 and their overall post-intervention GPA was 2.40, representing a positive overall change of 0.62 moving the mean score for this group from being in the middle of the range for the award of a Third Class Honours degree to the middle of the range for the award of a Lower Second Class degree (one whole classification higher). Of the 21 students, 18 had an increase in their GPA (three of whom had increases above 1.5), and three participants saw a drop in their GPA in semester 2. This drop was most evident in the lowest student percentile whereas increases in GPA were more evenly distributed across the cohort. Whilst the average increase in GPA was 0.68, the student with the lowest GPA at the start had an increase of 0.69 and the student with the highest initial GPA had an increase of 1.33. 
Table 3. Mentor advice and impact on individual participants GPA and course failures.

\begin{tabular}{|c|c|c|c|c|c|c|c|c|c|c|c|c|}
\hline \multirow[t]{2}{*}{ Student } & \multicolumn{3}{|c|}{ Semester 1} & \multicolumn{5}{|c|}{ Identified Challenges } & \multirow[b]{2}{*}{\begin{tabular}{l}
\multicolumn{1}{c}{ Mentor advice } \\
AC-Attend classes \\
CL-Reduce course load \\
FS-Increase family \\
support \\
ST-Set study schedule \\
SG-Study group \\
RD-Reduce distractions \\
DL-Decrease leisure time \\
AS- Academic support \\
LO-Use course syllabus \\
IE-Increase exercise \\
TS-Use travel time to \\
study \\
TT-Reduce travel time \\
LE-Sit closer to front of \\
class \\
GS- Goal setting \\
NS-No solution \\
EQ-Use exam questions \\
SW-Stop work \\
PS-Increase social \\
activities \\
IS-Increase sleep
\end{tabular}} & \multicolumn{3}{|c|}{ Semester 2} \\
\hline & GPA & $\begin{array}{c}\text { Courses } \\
\text { taken }\end{array}$ & $\begin{array}{c}\text { Courses } \\
\text { failed }\end{array}$ & 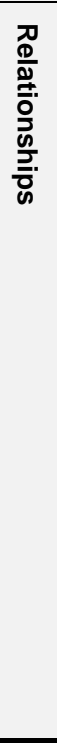 & 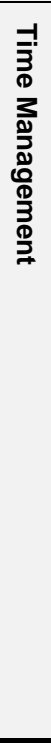 & 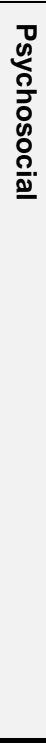 & 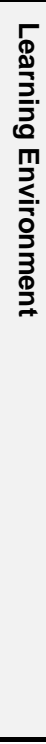 & 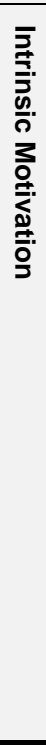 & & GPA & $\begin{array}{c}\text { Courses } \\
\text { taken }\end{array}$ & $\begin{array}{l}\text { Courses } \\
\text { failed }\end{array}$ \\
\hline $\mathbf{A}$ & 0.14 & 5 & 4 & & & & $\checkmark$ & $\checkmark$ & $\mathrm{AC} ; \mathrm{CL}$ & 0.83 & 5 & 3 \\
\hline B & 0.25 & 5 & 2 & $\checkmark$ & & & & & RD; FS & 0.21 & 5 & 4 \\
\hline C & 0.72 & 5 & 3 & & & $\checkmark$ & $\checkmark$ & & RD; CL & 1.59 & 5 & 2 \\
\hline D & 0.99 & 6 & 3 & $\checkmark$ & & $\checkmark$ & $\checkmark$ & & $A C ; D L$ & 1.35 & 5 & 3 \\
\hline $\mathbf{E}$ & 1.14 & 4 & 2 & $\checkmark$ & & & & & FS & 3.21 & 5 & 0 \\
\hline $\mathbf{F}$ & 1.14 & 6 & 3 & & & & $\checkmark$ & & AS & 1.10 & 5 & 1 \\
\hline G & 1.40 & 6 & 2 & $\checkmark$ & & $\checkmark$ & $\checkmark$ & & CL; LO; LE & 1.96 & 5 & 1 \\
\hline $\mathbf{H}$ & 1.55 & 5 & 2 & & $\checkmark$ & $\checkmark$ & $\checkmark$ & & SW; PS & 2.70 & 6 & 1 \\
\hline I & 1.58 & 6 & 1 & & & $\checkmark$ & $\checkmark$ & $\checkmark$ & CL; TS; IE & 2.02 & 6 & 1 \\
\hline $\mathbf{J}$ & 1.63 & 6 & 2 & & & & $\checkmark$ & $\checkmark$ & $\mathrm{IE} ; \mathrm{GS}$ & 2.54 & 5 & 0 \\
\hline $\mathrm{K}$ & 1.66 & 4 & 2 & & & & $\checkmark$ & $\checkmark$ & ST; IE & 2.30 & 6 & 1 \\
\hline $\mathbf{L}$ & 1.74 & 6 & 1 & $\checkmark$ & & & & $\checkmark$ & SG; ST & 2.06 & 6 & 2 \\
\hline M & 1.80 & 3 & 1 & & & $\checkmark$ & $\checkmark$ & $\checkmark$ & LO; EQ & 3.31 & 3 & 0 \\
\hline $\mathbf{N}$ & 1.93 & 6 & 1 & & & $\checkmark$ & & & IS & 2.55 & 6 & 1 \\
\hline 0 & 2.07 & 5 & 1 & & & & $\checkmark$ & $\checkmark$ & AS & 2.46 & 6 & 1 \\
\hline $\mathbf{P}$ & 2.49 & 6 & 1 & & $\checkmark$ & $\checkmark$ & & & IS; TT; ST & 2.62 & 6 & 0 \\
\hline $\mathbf{Q}$ & 2.74 & 6 & 1 & & $\checkmark$ & $\checkmark$ & & $\checkmark$ & IS; SG; DL & 1.93 & 6 & 1 \\
\hline $\mathbf{R}$ & 2.82 & 6 & 1 & & & $\checkmark$ & $\checkmark$ & $\checkmark$ & LE; ST; GS & 3.05 & 6 & 0 \\
\hline $\mathbf{s}$ & 2.93 & 4 & 1 & & & & $\checkmark$ & $\checkmark$ & RD; IS; SG; IE & 4.26 & 5 & 0 \\
\hline $\mathbf{T}$ & 0.86 & 5 & 1 & & & & $\checkmark$ & & ST & 1.95 & 5 & 0 \\
\hline $\mathbf{U}$ & 0.58 & 3 & 2 & & & & $\checkmark$ & & $E Q$ & 2.45 & 4 & 0 \\
\hline
\end{tabular}

For the non-participating students who were deemed to be 'at risk' at the end of semester 1 , GPAs at the start ranged from 0.55-2.83 and the semester two GPAs ranged from 0.5-3.23. One student in this group had an increase of over 1.5, one showed no improvement, and four had decreased GPAs. The average GPA for the non-intervention group in semester one was 
1.71 and 1.96 at the end of semester 2, showing an average increase of 0.25 . From this we can see that the mentored cohort increased their GPA by an average of $35 \%$ whereas the non-mentored group only increased by $15 \%$ (see Table 4).

Table 4. Mean GPAs of mentored and non-mentored students 'at risk'.

\begin{tabular}{|l|l|l|l|}
\hline & $\begin{array}{l}\text { Mean Semester 1 } \\
\text { GPA }\end{array}$ & $\begin{array}{l}\text { Mean Semester 2 } \\
\text { GPA }\end{array}$ & $\begin{array}{l}\text { Mean GPA } \\
\text { increase }\end{array}$ \\
\hline Mentored cohort & 1.78 & 2.40 & $0.62(35 \%)$ \\
\hline Non-mentored cohort & 1.71 & 1.96 & $0.25(15 \%)$ \\
\hline
\end{tabular}

The mentoring sessions revealed that the biggest challenge faced by the participating students related to the learning environment, with 16 of the 21 participants identifying barriers such as issues with transport to and from university, poor study habits, low personal goals, and a perceived lack of academic support. To address these challenges the four main pieces of advice offered were that students should set study schedules, increase levels of exercise, increase sleep, and reduce course load. The advice to set study schedules was offered to five students, who all made significant improvements in their GPAs. Guidance on reducing course workload seemed like good pragmatic advice and was offered to four students (all of whom increased their GPAs); however, only one of these students actually reduced their course workload.

Very little advice was offered with regard to relationships, and this might be a function of the mentor being an academic rather than a counsellor. Surprisingly, very little advice was offered on the concept of time management - previous work (Adams and Blair, 2019) had identified that engineering staff and students in this particular context felt time management was a particular area of weakness. Psychosocial challenges were identified among ten of the participants, and advice to them concentrated on dealing with reducing distractions, reducing workload and creating a better work-life balance. Advice linked to intrinsic motivation was also offered to ten students and tended to focus on study skills, goal setting and increased levels of exercise. This advice shows a balance between the physical and the pragmatic, and highlights some of the limitations of a self-selecting mentoring study that is focused on 
guidance and support rather than on creating formalised plans that students should follow. Other limitations of this study relate to the unknown - where other external factors that were outside of the intervention's control may have had an impact of the students. Loddick and Coulson (2020) similarly found that attending learning development tutorials had a positive impact on student attainment levels but found it hard to attribute causality due to the range of unknown external factors that influence student development. However, the overall trend and the overall scale of improvement after this mentoring intervention does suggest a level of causality. Similarly, there may be individual factors that are hard to track and assess. For example, whilst discussions in the mentoring sessions generated targets relating to students increasing their level of exercise and sleep, it is not possible to see any direct quantitative outcomes from these strategies. It is also important to reflect on the practicality of introducing such schemes. This intervention involved a lot of one-to-one support, and whilst the results are evident, the process was unsustainable. This meant that subsequent iterations of the programme involved group mentoring. The questioning approach, outlined by Attribution Theory, was still used in these group sessions, and improvements were also seen in GPAs; however, the multi-faceted context of group mentoring makes it harder still to assign specific credit for increases in GPA. Further, because students tended to be offered two or three strategies, it is not possible to unpick which specific strategies had any specific impact. Rather, it is better to suggest that, based on the overall GPA outcomes, the intervention as a whole was successful.

\section{Conclusion}

Determining the attributes linked to past successes and failures may be a useful tool for students as they navigate current challenges (workload, inflexible curriculum, and changes in content delivery and assessment) associated with poor academic progress (AWE, 2005). Mentoring based on a series of questions that guide students towards self-discovery of the reasons for current failures versus past successes can help students to make the changes needed to improve their academic performance. The quality and focus of the mentoring does not seem to be as important as the actual mentoring process itself. Perhaps implementing a 
mentoring scheme conveys the implicit message to students that they are valued and should be supported.

The positive changes in the participating students' GPAs and the reduction in course failures, as presented in this paper, suggest a successful overall intervention based upon a mentoring process. Similar overall findings have been reported elsewhere. In a study of 339 mentored undergraduates, matched and compared to un-mentored students for gender, ethnicity and GPA, Campbell and Campbell (1997) found that after a year of mentoring, students earned higher GPAs (2.45 vs 2.29), completed more units of study (9.33 vs 8.49) and had a lower dropout rate (14.5\% vs $26.3 \%)$. Other studies also show a positive correlation between mentoring and academic achievement (Anderson, 1995; Gentry, 2012; Terenzini et al., 1996). However, it should be noted that within the data there were still instances of student regression, and further work is needed to establish the specific reasons for such outcomes.

A number of factors are key to understanding how students who have been identified as 'at risk' might best be supported in attaining more positive future outcomes, and assisting students in shifting from a self-defeating to a self-enhancing attributional style can be beneficial for maintaining student self-confidence and addressing retention rates (Fishman and Husman, 2017). In this case, the focus was on engineering students, but the strategies suggested during the mentoring programme were not engineering-specific, covering topics that would be relevant to students in any subject area, suggesting that introducing a similar mentoring scheme is likely to show benefits for all students. In implementing similar mentoring schemes it is worth considering that students are likely to base future decisions on past outcomes (AWE, 2005; Martinko, 2018), that the development of critical thinking skills involves focused academic support, and that students are at particular risk when trying to balance their studies and external factors (Gentry, 2012; 2014).

The intervention outlined in this paper used Attribution Theory as a means of developing a mentoring programme that used questioning as a tool for examining students' selfperceptions of their abilities. This approach included both a functional and an emotional role, with primary emphasis on the functional aspects of mentoring. This intervention adds to the 
current literature on the impact of mentoring and expands the knowledge base by showing how focused questions to 'at risk' students can help them to see retrospective causal attributions and use these as the foundation for setting specific targets that that will help them in their studies. This particular mentoring programme was small scale and local to one department, but it is important to consider how successful interventions might be scaled up into an institutional framework so that learning development can be seen as a built-in mechanism rather than a bolt-on one (Mclntosh and Barden, 2019). In this particular department, scaling up the process involved moving from one-to-one mentorship to group mentorship, but wider, context-specific approaches should be explored. Without intervention it is still possible (as the evidence here shows) for students to increase their levels of attainment; however, there is evidence in this study that such increases are greatly enhanced through mentoring.

\section{References}

Adams, R.V. and Blair, E. (2019) 'Impact of time management behaviors on undergraduate engineering students' performance', SAGE Open, 9 (1), pp.1-11, https://doi.org/10.1177\%2F2158244018824506.

Ajjawi, R., Boud, D., Zacharias, N., Dracup, M. and Bennett, S. (2019) 'How do students adapt in response to academic failure?' Student Success, 10 (3), pp.84-91, https://doi.org/10.5204/ssj.v10i3.1403.

Anderson, G.N. (1995) 'Mentors and proteges: the influence of faculty mentoring on undergraduate academic achievement', Meeting of the Association for the Study of Higher Education, Orlando, Florida, 2-4 November. Available at:

https://files.eric.ed.gov/fulltext/ED400761.pdf (Accessed: 3 January 2021). 
Arsenijević, O., Podbregar, I. and Šprajc, P. (2020) 'Determinants of successful business student mentoring in higher education: fundamental or a fad?', International Journal of Economics and Law, 28 (1) UDC: 378-057.175.

Armstrong, J. (1996) 'Workload in engineering courses and how to reduce it', 8th Annual Conference of the Australasian Association for Engineering Education, Sydney, Australia 6-9 December. Available at:

http://citeseerx.ist.psu.edu/viewdoc/download?doi=10.1.1.398.9732\&rep=rep1\&type=p df (Accessed: 3 January 2021).

AWE (2005) Overview: Attribution Theory. Available at http://aweonline.org/attributionweb 032205 001.pdf (Accessed: 3 January 2021).

Campbell, T.A. and Campbell, D.E. (1997) 'Faculty/student mentor program: effects on academic performance and retention', Research in Higher Education, 38 (6), pp.727742, https://doi.org/10.1023/A:1024911904627.

Campbell, T.A. and Campbell, D.E. (2007) 'Outcomes of mentoring at-risk college students: Gender and ethnic matching effects', Mentoring \& Tutoring, 15 (2), pp. 135-148, https://doi.org/10.1080/13611260601086287.

Cedefop (2020) Identification of learners at risk of early. Available at:

https://www.cedefop.europa.eu/da/toolkits/vet-toolkit-tackling-earlyleaving/intervention-approaches/identification-learners-risk-early-leaving (Accessed: 3 January 2021).

Chesler, N.C. and Chesler, M.A. (2002) 'Gender-informed mentoring strategies for women engineering scholars: on establishing a caring community', Journal of Engineering Education, 91 (1), pp.49-55, https://doi.org/10.1002/j.2168-9830.2002.tb00672.x. 
Crocker, R.M., Kahla M. and Allen, C. (2014) 'Fixing advising: A model for faculty advising.' Research in Higher Education Journal 26.

Decker, P.J., Durand, R., Ayadi, F., Whittington, E. and Kirkman, D. (2014) 'Self-assessment of management competencies and intention to change', Academy of Educational Leadership Journal, 18 (4), pp. 129-147.

DeNeve, K.M. and Cooper, H. (1998) 'The happy personality: a meta-analysis of 137 personality traits and subjective well-being', Psychological Bulletin, 124 (2), pp.197229, https://doi.org/10.1037/0033-2909.124.2.197.

Eby, L.T., Rhodes, J.E. and Allen, T.D. (2007). 'Definition and evolution of mentoring', in Allen T.D. and Eby, L.T. (eds.) The Blackwell handbook of mentoring: a multiple perspectives approach. Oxford: Blackwell Publishing, pp.7-20.

Eby, L.T., Allen, T.D., Evans, S.C., Ng, T. and DuBois, D.L. (2008) 'Does mentoring matter? A multidisciplinary meta-analysis comparing mentored and non-mentored individuals', Journal of Vocational Behavior, 72 (2), pp. 254-267, https://dx.doi.org/10.1016\%2Fj.jvb.2007.04.005.

England, P. and Li, S. (2006) 'Desegregation stalled: the changing gender composition of college majors, 1971-2002', Gender and Society, 20 (5), pp. 657-677, https://doi.org/10.1177\%2F0891243206290753.

Fishman, E.J. and Husman, J. (2017) 'Extending attribution theory: considering students' perceived control of the attribution process', Journal of Educational Psychology, 109 (4), pp. 559-573, https://psycnet.apa.org/doi/10.1037/edu0000158.

Foss, K.A., Foss, S.K., Paynton S. and Hahn, L. (2014) 'Increasing college retention with a personalized system of instruction: a case study', Journal of Case Studies in Education, 5. 
Fouad, N.A. and Santana, M.C. (2017) 'SCCT and underrepresented populations in STEM fields: moving the needle', Journal of Career Assessment, 25 (1), pp.24-39, https://doi.org/10.1177\%2F1069072716658324.

Fox, M. F. (2001) 'Women, science, and academia: graduate education and careers', Gender \& Society, 15 (5), pp.654-666, https://doi.org/10.1177\%2F089124301015005002.

Gentry, R. (2012) 'Making college a success by assessing and navigating candidates' study habits', Research in Higher Education Journal, 18.

Gentry, R. (2014) 'Sustaining college students' persistence and achievement through exemplary instructional strategies', Research in Higher Education Journal, 24.

Gould, M.S., Velting, D., Kleinman, M., Lucas, C., Thomas, J.G. and Chung, M. (2004) 'Teenagers' attitudes about coping strategies and help-seeking behavior for suicidality', Journal of the American Academy of Child \& Adolescent Psychiatry, 43 (9), pp. 11241133, https://doi.org/10.1097/01.chi.0000132811.06547.31.

Gräbel, B.F. (2017) The relationship between wellbeing and academic achievement: a systematic review. Unpublished master's thesis. University of Twente.

Harmening, D.S. and Jacob, S.A. (2015) 'Institutional factors that positively impact first-year students' sense of well-being', Journal of Case Studies in Education, 7.

Jemal, J. (2012) 'Assessing major adjustment problems of freshman students in Jimma University', Ethiopian Journal of Education and Sciences, 7 (2), pp. 1-14.

Johnson, W.B. (2007) 'Student-faculty mentorship outcomes', in Allen, T.D. and Eby. L.T (eds.) The Blackwell handbook of mentoring: a multiple perspectives approach. Oxford: Blackwell Publishing, pp.189-210. 
Katz, L.G. (1993) 'All about me: are we developing our children's self-esteem or their narcissism?' American Educator: The Professional Journal of the American Federation of Teachers, 17 (2), pp. 18-23.

Kausar, R. (2010) 'Perceived stress, academic workloads and use of coping strategies by university students', Journal of Behavioural Sciences 20 (1), pp. 31-45, https://scinapse.io/papers/2188512843.

Komarraju, M., Musulkin S. and Bhattacharya, G. (2010) 'Role of student-faculty interactions in developing college students' academic self-concept, motivation, and achievement', Journal of College Student Development, 51 (3), pp. 332-342, https://psycnet.apa.org/doi/10.1353/csd.0.0137.

Linley, J.L. and George-Jackson, C.E. (2013) 'Addressing underrepresentation in STEM fields through undergraduate interventions', New Directions for Student Services, 144, pp.97102, https://doi.org/10.1002/ss.20073.

Lipton, L., Wellman B.M. and Humbard, C. (2003) Mentoring matters: A practical guide to learning-focused relationships, Sherman, CT: MiraVia, LCC.

Lowe, D.B. and Johnston, A.J. (2008) 'Engineering admissions criteria: focusing on ultimate professional success', WACE/ACEN Asia Pacific Conference, Sydney, Australia, 30 September - 3 October. Available at:

file:///C:/Users/Sarah/Downloads/Engineeringadmissionscriteriafocusingonultimateprof essionalsuccess-LoweJohnston2008.pdf (Accessed: 3 January 2021)

Martinko, M. (2018) Attribution theory: An organizational perspective. Boca Raton: Routledge. 
McCoy, D.L., Winkle-Wagner, R. and Luedke, C.L. (2015) 'Colorblind mentoring? Exploring white faculty mentoring of students of color', Journal of Diversity in Higher Education, 8 (4), pp..225-242, http://dx.doi.org/10.1037/a0038676.

Morisano, D., Hirsh, J.B., Peterson, J.B., Pihl, R.O. and Shore, B.M. (2010) 'Setting, elaborating, and reflecting on personal goals improves academic performance', Journal of Applied Psychology, 95 (2), pp. 255-264, https://psycnet.apa.org/doi/10.1037/a0018478.

Mullen, C.A. (2007) 'Naturally occurring student-faculty mentoring relationships: a literature review', in Allen, T.D. and Eby. L.T (eds.) The Blackwell handbook of mentoring: A multiple perspectives approach. Oxford: Blackwell Publishing, pp.119-138.

Loddick, A. and Coulson, K. (2020) 'The impact of Learning Development tutorials on student attainment', Journal of Learning Development in Higher Education. Plymouth, UK, (17). Available at: https://journal.aldinhe.ac.uk/index.php/jldhe/article/view/558 (Accessed: 9 October 2020).

McIntosh, E. and Barden, M. (2019) 'The LEAP (Learning Excellence Achievement Pathway) framework: a model for student learning development in higher education', Journal of Learning Development in Higher Education. Plymouth, UK, 0(14). Available at: https://journal.aldinhe.ac.uk/index.php/jldhe/article/view/466 (Accessed: 5 October 2020).

Sax, L.J. (2008) The gender gap in college: Maximizing the developmental potential of women and men. San Francisco: Jossey-Bass.

Shelton, E.N. (2003) 'Faculty support and student retention', Journal of Nursing Education, 42 (2), pp. 68-76, https://doi.org/10.3928/0148-4834-20030201-07. 
Terenzini, P.T., Pascarella, E.T. and Blimling, G.S. (1996) 'Students' out-of-class experiences and their influence on learning and cognitive development: a literature review', Journal of College Student Development 37 (2), pp.149-162.

Wilson, C.J. and Deane, F.P. (2010) 'Help-negation and suicidal ideation: the role of depression, anxiety and hopelessness', Journal of Youth and Adolescence 39 (3), pp.291-305, https://doi.org/10.1007/s10964-009-9487-8.

Young-Jones, A.D., Burt, T.D., Dixon, S. and Hawthorne, M.J. (2013) 'Academic advising: does it really impact student success?', Quality Assurance in Education 21 (1), pp.719, https://doi.org/10.1108/09684881311293034.

Zachary, L. (2000) The mentor's guide: facilitating effective learning relationships. San Francisco, CA: Jossey-Bass.

Zhang, Y., Fei, Q., Quddus, M. and Davis, C. (2014) 'An examination of the impact of early intervention on learning outcomes of at-risk students', Research in Higher Education Journal, 26 (10), pp. 1-12.

\section{Author details}

Chris Maharaj is Senior Lecturer in Materials and Manufacturing in the Department of Mechanical and Manufacturing Engineering at the University of the West Indies, St. Augustine, Trinidad and Tobago. His present teaching and research interests are in alternative use of waste materials, mechanical design optimization, failure analysis, component life assessment, asset management, innovation management, and enhancing student motivation.

Erik Blair is Senior Lecturer in Higher Education Research and Practice at the University of West London. He has been an educator for over twenty years and has taught in various 
universities in the UK and overseas. He is interested in contextual and sociological aspects of education, and his teaching is underpinned by good educational practice as espoused in the literature as well as through his own reflective practice.

Margo Burns was the Director of the Centre for Excellence in Teaching \& Learning at the University of the West Indies, St. Augustine, Trinidad and Tobago.

\section{Dedication to Margo Burns}

Drs Blair and Maharaj dedicate this study to the late Dr Margo Burns. Dr Maharaj had the great pleasure of working with Dr Burns on several projects. If he had only one word to describe her, it would be generous. She was generous with her time, knowledge and kindness. Dr Maharaj will aim to keep the memory of Dr Burns alive through the reciprocation of this generosity. 